\title{
ANALYZING DEMOGRAPHIC CHARACTERISTICS OF THE SECURITY INVESTORS: AN APPLICATION TO TURKEY
}

\section{DOI: 10.17261/Pressacademia.2015414376}

\section{Cansu Tanyolac', Mehmet Baha Karan²}

'Baskent University. ctanyolac@baskent.edu.tr

${ }^{2}$ Hacettepe University. mbkaran@ hacettepe.edu.tr

\section{Keywords}

Risk tolerance, individual investor, Turkey, logistic regression, demographic variables

\section{JEL Classification}

G02, G20, J10

\begin{abstract}
Behavioral finance theories, which assert that individual investors do not behave rationally in their decision-making process, have been gaining importance in last twenty years. In this study, the data of Income and Living Conditions Survey of Turkish Statistical Institute (TURKSTAT) which were conducting to individual investors in Turkey were used. We analyzed the data employing the logistic regression methodology for the period of $2009-2012$. The result indicated that individuals' risk tolerances and investment decisions were affected by demographic characteristics like age group, education level, marital status, as well as socio-economic characteristics like default risk, income risk and income level.
\end{abstract}

\section{MENKUL KIYMET YATIRIMCILARININ DEMOGRAFIK ÖZELLIKLERININ INCELENMESI: TÜRKIYE ÜZERINDE BIR UYGULAMA}

\section{Anahtar Kelimeler \\ ÖZET}

Risk toleransı, bireysel yatırımcı, Türkiye, lojistik regresyon, demografik değişkenler

JEL Sınıflandırması G02, G20, J10
Bireysel yatırımcıların karar verme sürecinde rasyonel davranmadıklarını öne süren davranışsal finans teorileri, son yirmi yıldır giderek önem kazanmaktadır. Bu teori kapsamında bu çalışmada, Türkiye İstatistik Kurumu (TÜiK)'ndan temin edilen Gelir ve Yaşam Koşulları Anketi'nin 2009-2012 yılları arasındaki verilerinden yararlanılarak Türkiye'deki bireysel yatırımcılarla ilgili bir uygulama yapılmış ve lojistik regresyon analizi kullanılarak Türkiye'ye uygun bir model geliştirilmiştir. Elde edilen sonuçlar incelendiğinde; bireylerin risk toleranslarının ve yatırım kararlarının yaş grubu, eğitim seviyesi, medeni hâl gibi demografik özelliklerinin yanı sıra, borcunu ödeyebilme, gelir riski, gelir düzeyi gibi sosyo-ekonomik özelliklerden de etkilendiği görülmüştür. 


\section{GíRiş}

Bireyler, birikimlerini değerlendirmek amacıyla yatırım kararı alırken menkul kıymetin beklenen getirisini göz önünde bulundururlar. Geleneksel finans teorilerinin ortak varsayımlarına göre, yatırımcı oluşturduğu yatırım portföyünden elde ettiği faydanın maksimum düzeyde olmasını ister. Klasik teorilere göre, yatırım ne kadar riskliyse kıymetin beklenen getirisi de o kadar fazla olmaktadır. Bu kapsamda, riskten kaçınan bir birey riski yüksek olan kıymetlere yatırım yapmak istemeyecektir. Yatırımcının bu tercihi, yatırım yaptığı menkul kıymetin çeşidine de etki edecektir. Riski seven bir yatırımcı, hisse senedine yatırım yapmak isterken, riskten kaçınan bir yatırımcı, ya devlet tahvillerine yatırım yapmayı tercih edecek ya da portföyünde riski düşük olan kıymetlere daha fazla yer verecektir.

Yatırımcının riski ne ölçüde kabul edebildiği, onun risk toleransını ifade eder. Bireyin risk toleransı azaldıkça, yaptığı riskli yatırımlar da ona bağlı olarak azalacaktır. Bu sebeple risk toleransı, yatırımcıların finansal kararlar alırken gösterdikleri davranışlarını açıklayan, bireylerin risk karşısındaki tutumlarını ve ne kadar risk almaya hazır bulunduğunu gösteren önemli kavramlardan biridir. Risk toleransının değerlendirilmesi, uzun vadedeki yatırım hedeflerinin kararlaştırılması ve gerçekleştirilmesi bakımından çok önemlidir. Örneğin; risk toleransı düşük olan bireyler, uzun vadede bekledikleri yatırım hedeflerini karşılayamayabilir, hisse senetlerine yapmadıkları yatırımlar sebebiyle fırsat kayıpları yaşayabilirler. Aynı şekilde, risk toleransının yüksek olması da kısa vadeli yatırımlara yapılmayan yatırımlar sonucu gereksiz varlık kaybına neden olmaktadır.

Geleneksel finans teorilerinin ortak noktası, yatırımcıları getirilerini maksimum düzeye çıkartmak amacıyla hareket eden ve duygularının etkisi altında kalmadan kararlar verebilen rasyonel bireyler olarak kabul etmeleridir. Bireyin psikolojisini ve diğer etkisi altında kalabileceği demografik, sosyo-ekonomik vb. özelliklerin hiçbirini ele almayan bu teorilere göre, insanlar rasyoneldir ve yalnızca ekonomik güdülerle hareket etmektedirler. Son yıllarda özellikle davranışsal finans alanında yapılan çalışmalar, "homo ekonomikus" olarak tanımlanan bu rasyonel insanı sorgulamış ve insanların karar verme aşamasında sınırsız rasyonel davranış göstermediğini tespit etmiştir. Bu konuda Kahneman ve Twersky (1979)'nin ortaya attığı "beklenti teorisi”, davranışsal finansın teorik çerçevesini çizmiştir. Daha sonra Thaler (1985), Barber ve Odean (2001) gibi birçok bilim adamı da, bu teorinin gelişmesine katkı vermişlerdir.

Türkiye'de Basel II kurallarının uygulanmaya başlanması ile birlikte, kredi kullanan yatırımcıların riske karşı olan tutum ve davranışlarının incelenmesi de önem arz eder hâle gelmiştir. Son yıllarda bireysel yatırımcıların riske karşı tutumlarını inceleyen araştırmalar, yatırımcıların finansal davranışlarında demografik ve sosyo-ekonomik faktörlerin etkisi altında kaldığını göstermiştir. Yatırımcıların risk tolerans düzeylerinin ise cinsiyet, yaş grubu, eğitim seviyesi, medeni hâl, meslek grubu, gelir düzeyi, mal varlığı gibi demografik ve sosyo-ekonomik değişkenlerle ilişkili olduğu, bunun da yatırım kararlarını ciddi ölçüde etkilediği ortaya konmuştur.

Arslan ve Karan (2010), hane halkının kredi riskini ölçmeye yönelik yaptıkları çalışmalarında, yatıımcıların riske olan duyarlılığının yaş, eğitim, gelir gibi değişkenlerden etkilendiğini bulmuşlardır. Anbar ve Eker (2009) ve Saraç ve Kahyaoğlu (2011) da benzer şekilde cinsiyet, yaş, medeni durum, gelir düzeyi- net varlık, eğitim düzeyi, finansal bilgi 
seviyesi ve meslek grubu gibi demografik ve sosyo-ekonomik değişkenlerin bireysel yatırımcının finansal risk algısı üzerindeki etkilerini incelemişlerdir. Usul ve diğerleri (2002) ise, yatırımcıların hisse senedi edinimine etki eden sosyo-ekonomik faktörleri incelerlerken, bireyin kişilik özelliklerine ve diğer çevresel etkenlere de değinmişlerdir.

Son yıllarda gelişen bireysel bankacılık ve sermaye piyasaları kuruluşları, bireysel yatırımcıların tasarruflarını çekerek ekonomiye kaynak sağlamak ve yoğun rekabetin olduğu bu piyasalardan daha fazla pay almak için, bireysel yatırımcıların tercihlerine özellikle önem vermektedirler. Diğer taraftan, devlet kuruluşları ile düzenleyici otoritelerin de, ülke tasarruf düzeyini arttırmak ve pazarın daha iyi çalışmasını sağlamak için bireysel yatırımcıları doğru bir şekilde anlamaları gerekmektedir. Bu çalışmanın temel motivasyonu, bireysel yatırımcıların risk ve yatırım tercihlerini ortaya koyarak, finans kuruluşlarına ve düzenleyici kuruluşlara yol göstermektir.

Çalışmamızda, Türkiye İstatistik Kurumu (TÜiK)'ndan temin edilen Gelir ve Yaşam Koşulları Anketi'nin 2009-2012 yılları arasındaki verileri kullanılarak yatırımcıların menkul kıymet yatırım profilleri araştırılmıştır. Geniş bir veri seti kullanılması sayesinde, yıllar bazındaki değişiklikler açık bir şekilde değerlendirilmiştir. Menkul kıymete yatırım yapan Türkiye'deki 13979 hane reisine ait demografik ve sosyo-ekonomik özellikler incelenmiş, bu özelliklerin bireylerin risk tolerans düzeylerini ve yatırım kararlarını nasıl etkilediğini açıklamak amacıyla Türkiye için bir model geliştirilmiştir. Çalışmada, Türkiye'de menkul kıymete yatırım yapan bireysel yatırımcıların risk tolerans düzeyleri ve yatırım kararları; menkul kıymet yatırımcılarının borç ödeme sorunu yaşama durumları, gelir riski taşıma durumları, eğitim seviyeleri, yaş grupları, medeni hâlleri ve gelir düzeyleri dikkate alınarak, lojistik regresyon yöntemi ile analiz edilmiştir.

Araştırmada kullanılan verilerin, sadece 2009-2012 yıllarına ait verileri kapsaması ve kullanılan verilerin halka açık verilerle sınırlı olması, çalışmanın kısıtlarından biridir. Başka bir sınırlama ise, literatürdeki çalışmalarda bireysel yatırımcıların risk tolerans düzeylerini ve yatırım kararlarını etkileyen faktörlere dahil olan kişilik özellikleri ve psikolojik faktörlere aittir. Bu bilgiler, ilgili veri setinde tespit edilebilecek durumda olmadığından çalışmanın kapsamına alınmamış, yatırımcının sadece demografik ve sosyo-ekonomik özellikleri incelenmiştir. Ayrıca, hanehalkı reisinin cinsiyet bilgisine sahip olunmadığından, cinsiyet değişkenine dair değerlendirmeler yapılmamıştır. Çalışma, menkul kıymet yatırımına etki eden tüm demografik ve sosyo-ekonomik faktörleri modele dahil edememe sınırlılığına sahip olsa da, Türkiye'de menkul kıymete yatırım yapan bireysel yatırımcıların risk tolerans düzeylerine ve buna bağlı olarak yatırım kararlarına etki eden demografik ve sosyoekonomik faktörlerin, geniş bir veri seti ele alınarak araştırılması anlamında yapılan bir çalışma olması sebebiyle farklı bir çalışma olmuştur. Bununla birlikte pek çok çalışmadan farklı olarak, yatırımcılara risk eğilimlerini ölçen sorular sormaktan ziyade, yatırımcıların risk tolerans düzeylerini gerçek davranışları (menkul kıymet yatırımı yapma/yapmama) üzerinden açıklaması bakımından da çalışmanın literatüre katkı sağlayacağı ve bundan sonra yapılacak olan daha kapsamlı çalışmalara yol gösterici bir niteliğe sahip olduğu düşünülmektedir.

Çalışmada, menkul kıymet yatırımcılarının risk tolerans düzeylerini ve risk algılamalarını etkileyen faktörler, literatürde oraya konulan bulgular çerçevesinde incelenmiş ve sahip olunan demografik ve sosyo-ekonomik özelliklerin, bireyin risk değerlendirme yöntemini 
ve aldığı yatırım kararlarını etkilediği varsayımında bulunulmuştur. Çalışmanın temel amacı, Türkiye'deki menkul kıymet yatırımcılarının risk toleranslarını ve yatırım kararlarını etkileyen demografik ve sosyo-ekonomik özelliklerinin değerlendirilmesidir.

Çalışma, dört ana bölümden oluşmaktadır. Çalışmanın ilk bölümünde, davranışsal finans kavramı ve bu kavramın geleneksel teorilerden farklılaşan kısımları ele alınmıştır. Daha sonra ise, yatırımcıların risk toleransları ile demografik ve sosyo-ekonomik özellikleri arasındaki ilişkiyi inceleyen önceki çalışmalar incelenmiştir. Çalışmanın ikinci bölümünde, TÜik'ten temin edilen Gelir ve Yaşam Koşulları Anketi'nin 2009-2012 yılları arasındaki 4 yıllık zaman dilimini kapsamakta olan verileri detaylı olarak açıklanmış, analizde kullanılan yöntem ve bu yöntemin üstünlüklerine de değinilmiştir. Çalışmanın üçüncü bölümünde, lojistik regresyon analiz yöntemi kullanılarak analiz edilen verilerin bulguları incelenmiş, elde edilen bulgular literatürdeki çalışmalarla karşılaştırılmıştır. Çalışmanın dördüncü ve son bölümünde ise, yapılan çalışmanın sonuçları yorumlanmış ve çalışmanın sonraki çalışmalara yapacağı katkı ve tavsiyelere yer verilmiştir.

\section{DAVRANIŞSAL FINANS TEORISI VE LITERATÜRDEKI ÇALIŞMALAR}

1970'li yıllardan beri finans, insanların akılcı davrandıkları ve geleceğe dair öngörülerinde tarafsız oldukları varsayımıyla hareket etmektedir. Etkin piyasalar hipotezine göre, yatırımcılar aynı riski alarak gerçekleştirdikleri yatırımlarında, hiçbir şekilde anormal getiri elde edememektedir. Kendileri için en iyisini seçtikleri varsayılan yatırımcılar için, pek çok araç üretilmiştir. CAPM, AFT ve opsiyon fiyatlaması gibi fiyatlama modelleri ile, varlıkların değerlenmesi ve risk ve getirinin anlaşılması mümkün olabilmektedir (Tufan, 2008: 20-21). Insan psikolojisini ele almayan geleneksel teorilere göre, insanlar rasyoneldir ve sadece ekonomik güdülerle hareket etmektedirler. Fakat, finans alanındaki deneysel çalışmalar geleneksel teorilerin sıklıkla bahsettiği "Homo ekonomikus" olarak tanımlanan rasyonel insanı sorgulamıştır. "Homo ekonomikus" olarak tanımlanan insan, yatırım kararlarında her zaman kendi çıkarlarını en üst düzeyde gözeterek, rasyonel davranan bir bireydir. Halbuki insanın yaradılışı gereği, sınırsız rasyonel olabilmesi mümkün değildir.

Finans alanındaki deneysel çalışmalar, bireyin bu karmaşık zihin yapısını sorgulamaları neticesinde, karar verme aşamasında insanların sınırsız rasyonellikten ayrıldığını ispat etmişlerdir. Bu ayrılma, duruma özgü, kişisel ya da belirli kişilerle ilgili olmamakla birlikte, yatırımcıların büyük kısmını ilgilendirmektedir (Barak, 2008: 66). Bir başka deyişle, davranışsal finans, piyasadaki yatırımcılar için tam bir rasyonellikten bahsetmenin oldukça zor olduğunu ileri sürmektedir.

Son yıllara kadar bazı savunucuları olmasına rağmen, genellikle ekonomiden ve pozitif bilimlerden ayrı olarak tutulan psikoloji, 1979 yılında Daniel Kahneman ve Amos Twersky tarafından "beklenti teorisi" ortaya konulduğunda, daha çok kabul görmeye başlamıştır. $\mathrm{Bu}$ teorinin ortaya konmasından sonra, bireylerin yatırım kararlarını etkileyen bilişsel ve duygusal eğilimleri açıklamaya yönelik yapılan çalışmalar da, "davranışsal finans" kavramının temellerini atmıştır. Kahneman ve Twersky (1979) çalışmalarında, bireylerin karar verme süreçlerinde insan psikolojisinin rolünü ve önemini ortaya koymuşlardır. Bu çalışmaların sonucunda, insanların belirsizlik altında karar verme durumunda, beklenen fayda teorisine ait rasyonel kuralların yatırım kararlarını açıklamada yetersiz kaldığı ortaya çıkmıştır. Kahneman ve Twersky (1979), insanların yatırım tercihlerinin rasyonel olmadığını, bu tercihlerin bireylerin psikolojilerine ve algılamalarına bağlı olarak göre 
değişiklik gösterebileceğini ifade etmişlerdir. Bu araştırma ve çalışmalar ışığında, Kahneman 2002 yılında nobel ödülü kazanarak davranışsal finans alanının akademik çevrece kabulüne ve gelişimine önemli katkı sağlamıştır.

Literatürde yatırımcının risk toleransını ölçmekte en çok kullanılan demografik ve sosyoekonomik değişkenler olan cinsiyet, meslek, eğitim, medeni durum, yaş ve gelir durumlarının yatırımcının risk toleransı ile ilişkileri alt başlıklar halinde ele alınmıştır.

\section{Cinsiyet ve Risk Toleransı İlişkisi}

Literatürde, cinsiyet ve risk toleransına etkisi üzerine yapılan çalışmaların büyük bir çoğunluğu, erkek yatırımcıların kadın yatırımcılara oranla, daha fazla risk toleransına sahip olduğunu ortaya koymuştur. Yine bu çalışmalara göre, kadınların yatırımlarında daha az risk almak istemelerinin altında iki temel neden yatmaktadır. Bunlardan ilki, kadınların erkeklere oranla daha az gelir durumuna ve mal varlığına sahip olmaları (Bajtelsmith ve Bernasek, 1996), ikincisi ise kadınların finansal bilgi bakımından erkeklere göre daha az donanımlı olmalarıdır (Anbar ve Eker, 2009; Dwyer ve diğerleri, 2002). Gelir seviyesinin yüksek olması, yatırımcıya bir finansal güvence yaratarak karşılaşılan riskin tolere edebilmesine imkân tanırken, finansal alanda iyi derecede bilgi sahibi olunması da, yatırımcıların karar verme sürecinde daha doğru, daha etkin ve kendilerine daha güvenli bir şekilde davranmalarını sağlamaktadır. Bunlara ilaveten, bazı çalışmalar cinsiyetin risk toleransı üzerindeki etkisinin psikolojik, biyolojik ve karakteristik birtakım özelliklere de bağlı olduğuna dikkat çekmiştir. Kadınların "riskten kaçınan” bireyler olarak algılanmasının sebebini toplumda cinsiyetler hakkında geliştirilmiş basmakalıplar olarak açıklayan çalışmalar da bulunmaktadır (Maxfield ve diğerleri, 2010; Roszkowski, 2005). Bunun yanı sıra literatürdeki çalışmaların büyük bir bölümü, cinsiyetin bireyin risk toleransı üzerinde etkili olan bir faktör olduğunu savunsa da, bu konuda karşıt görüşler de mevcuttur (Nelson, 2012; Schubert ve diğerleri, 2000; Harrison ve diğerleri, 2007; Embrey ve Fox, 1997).

\section{Meslek ve Risk Toleransı iliş̧kisi}

Literatürde, demografik özelliklerin yatırımcıların sahip oldukları risk tolerans düzeyleri üzerine etkisini inceleyen çalışmaların bir bölümü, yatırımcıları "kendi mesleklerine sahip olanlar ve olmayanlar" olarak ele alırken (Grable, 1997; Anbar ve Eker, 2009; Brown ve diğerleri, 2007; Saraç ve Kahyaoğlu, 2011), bazı çalışmalar da yatırımcıları "profesyonel mesleklere sahip olanlar ve olmayanlar" olarak (Halliassos ve Bertaut, 1995; Sultana ve Pardhasaradhi, 2011; Antonites ve Wordsworth, 2009) sınıflandırmıştır. Genel olarak, kendi işine sahip olan bireylerin daha yüksek gelire ve özgüvene sahip olacağı düşünüldüğünden yatırım kararlarında daha fazla risk alabilecekleri ileri sürülmektedir. Benzer şekilde, profesyonel mesleklerde çalışan bireylerin sahip oldukları tecrübe ve finansal bilgi düzeyi sayesinde risk tolerans düzeylerinin yüksek olacağı düşünülmektedir. Literatürde, yatırımcının meslek grubunun risk toleransı üzerinde diğer çalışmaların karşı görüşünü savunan ya da meslek grubunun risk toleransı üzerinde etkisi olmadığını iddia eden herhangi bir çalışmaya rastlanmamıştır. Çalışmaların tamamı, meslek grubunun yatırımcının risk toleransı üzerinde pozitif bir etkiye sahip olduğu yönünde görüş birliği içerisindedir. 


\section{Eğitim Seviyesi ve Risk Toleransı İlişkisi}

Literatürdeki çalışmalar, bireyin eğitim seviyesinin risk tolerans düzeyi üzerindeki etkisini ele alırken, iki temel faktör üzerine yoğunlaşmışlardır. İlk olarak, artan eğitim düzeyin bağı olarak yatırımcının daha prestijli ve daha fazla gelir getiren bir mesleğe sahip olabileceğini, bunun da yatırımcıya daha fazla gelir sağlayacağı öne sürülmüştür (Hallahan ve diğerleri, 2003). İkinci olarak da yatırımcının eğitim durumu, finansal bilgi düzeyini arttıran bir faktör olarak ele alınmıştır (Grable ve Joo, 2000, Sultana ve Pardhasaradhi, 2011). Yapılan çalışmalarda, genel olarak yatırımcının risk tolerans düzeyinin eğitim seviyesine bağı olarak arttığı gözlemlenmiştir (Grable ve Lytton, 2000; Ardehali, 2004, Hawley ve Fuji, 1993). Literatürdeki çalışmaların büyük çoğunluğu (Grable, 1997; Grable ve Lytton, 1999; Sung ve Hanna, 1996; Coleman, 2003) eğitim seviyesinin yatırımcın risk toleransı üzerinde pozitif bir etkisi olduğunu ileri sürse de, bu konuda karşıt görüşler de mevcuttur (Faff ve diğerleri, 2011).

\section{Medeni Durum ve Risk Toleransı iliş̧kisi}

Yatırımcıların risk toleransını belirlemeye yönelik olarak yapılan çalışmalarda, medeni durumun incelenmesi bireylere bağımlı olan bireyler açısından önem arz etmektedir; zira bireyin bağımlı olduğu ve bakmakla mükellef olduğu kimselerin sayısı, alacağı yatırım kararlarını ve risk miktarlarını etkilemektedir. Literatürdeki çalışmalar, yatırımcının risk toleransını medeni hallerine göre incelemelerinin yanı sıra, evli çiftlerin çocuk sahibi olma durumlarının risk tolerans düzeyleri üzerindeki etkilerini de araştırmışlardır. Literatürdeki araştırmaların bir bölümü, yatırımcının medeni durumunun birey üzerinde etkili olabilecek psikolojik etkileri üzerine odaklanırken (Saraç ve Kahyaoğlu, 2011; Grable ve Lytton, 1998) bir bölümü de yatırımcının medeni durumunun hanenin finansal durumu üzerindeki etkilerine odaklanmıştır (Watson ve McNaughton, 2007). Literatürde hanedeki bakmakla mükellef olunan kişi sayısının yatırımcının riske karşı tutumunu inceleyen çalışmalarda ise, yatırımcıların çocuk sahibi olup olmadığı ya da sahip olunan çocuk sayısı incelenmiştir (Riley ve Russon, 1995; Chaulk, 1997). Bununla birlikte, evli çiftlerin yatırımlarında "daha az risk almak istediği" savını desteklemeyen çalışmalar da mevcuttur (Sultana ve Pardhasaradhi, 2011; Grable, 2000; Faff ve diğerleri, 2003).

\section{Yaş ve Risk Toleransı ílişkisi}

Literatürdeki çalışmaların büyük bir kısmı, yatırımcının yaşının risk toleransı üzerinde etkili olduğu konusunda görüş birliği içerisindedir (Ardehali, 2004; Morin ve Surez, 1983; Hawley ve Fuji, 1993, Usul ve diğerleri, 2002). Bununla birlikte; yaşın risk toleransı üzerinde pozitif etkisi olduğunu öne süren çalışmalar kadar negatif etkisi olduğunu savunan çalışmalar da mevcuttur (Wang ve Hanna, 1997; Bellante ve Gren, 2004; Harrison ve diğerleri, 2007, Grable, 2000; Schooley ve Worden, 1999). Yaş ilerledikçe, insanların gelir kaynaklarının kısıtlanması ve sahip olduklarını kaybetme korkusu yaşamaları sebebiyle riskli yatırımcılardan daha fazla kaçındığını söylemek mümkündür. Fakat, aynı şekilde yaşın insana getirdiği tecrübe, finansal bilgi ve maddi birikim düşünüldüğünde, yatırımcılar yaşlandıkça daha fazla riski de göze alabileceklerdir (Wagner, 2011). Öte yandan; bazı çalışmalar, yaşın bireyin risk toleransı üzerinde herhangi bir etkisi olmadığını ileri sürmüştür (Grable ve Lytton, 1998; Sung ve Hanna, 1996). 


\section{Gelir Durumu (Mal Varlığı) ve Risk Toleransı İlişkisi}

Genel bir kanı olarak, yatırımcının gelir durumu arttıkça daha riskli yatırımlara yönelebileceği düşünülmektedir zira; yüksek gelire sahip yatırımcı karşılaştığı olası bir riski tolere edebilmek ve kayıplarını karşılayabilmek için diğer yatırımcılara oranla, daha fazla servet ve mal varlığına sahiptir (Watson ve McNaughton, 2007). Aynı şekilde, yatırımlarında daha fazla risk almak isteyen bireylerin ellerinde daha çok varlık tutmak istediği düşünülmektedir. Bu bakımdan, literatürde bu konuda yapılmış olan çalışmaların neredeyse tamamı (Grable, 1997; Ardehali, 2004; Hawley ve Fuji, 1993; Finke ve Huston, 2003; Grable ve diğerleri, 2006), gelir durumunun risk toleransı üzerinde pozitif etkisi olduğunu ileri sürmüşlerdir.

\section{VERILER VE YÖNTEM}

\section{Çalışmada Kullanılan Veri Seti İle İIgili Bilgiler}

Türkiye'de, menkul kıymete yatırım yapan bireysel yatırımcıların demografik ve sosyoekonomik özelliklerinin tespit edilmesi amacıyla, Tüik'ten temin edilen Gelir ve Yaşam Koşulları Anketi'nin 2009-2012 yılları arasındaki 4 yıllık verileri kullanılmıştır. Her yaştaki ferdin bilgilerini içeren çok geniş bir veri setine sahip olunduğundan, Türkiye'de menkul kıymete yatırım yapan bireysel yatırımcılar hane bazında incelenmiştir. Çalışmaya özellikle bu ankette sürekli olarak yer alan hanehalkları dahil edilmiştir. Ankette yer alan hanehalklarının \%75'i iki veya daha fazla yıl ankete dahil olmuştur. Bu dönem boyunca, ankette yer alan hanehalkı reislerinin ortalama gelir, gelir riski, eğitim ve yaş değerleri veri olarak kullanılmıştır. Hanehalkı reisi yaşı 15-19 yaş aralığından küçük olanlar, araştırmaya dahil edilmemiştir.

Veri setindeki toplam hanehalkı reisi sayısı, örneklem olarak ele alınmış, bunun için ferde ve haneye ait kesit veriler birleştirilerek, hanehalkını temsil eden hanehalkı reisi "referans kişi" değişkeninden bulunmuştur. Menkul kıymete sahip olan ve olmayan hanehalkı reisi sayıları ise aşağıdaki gibidir:

Tablo 1: Menkul Kıymete Sahip Olan ve Olmayan Hanehalkı Reisi Sayıları

\begin{tabular}{cc}
\hline Menkul kıymete sahip olan hanehalkı reisi sayısı & 8664 \\
Menkul kıymete sahip olmayan hanehalkı reisi sayısı & 5315 \\
\hline Toplam hanehalkı reisi sayısı & $\mathbf{1 3 9 7 9}$ \\
\hline
\end{tabular}

Literatürdeki çalışmalardan yola çıkılarak, hanehalkı reisinin cinsiyet, yaş, medeni hâl, eğitim seviyesi, meslek grubu, yaşadığı bölge ve gelir düzeyleri incelenmiştir. Gelir düzeyleri incelenirken, olası oransal farklılıkları önlemek için gelir miktarının logaritması alınmıştır. Hanehalkının borç ödeme riski yaşama durumu (default risk), son bir yıl içerisinde kredi kartı, taksit ve kira gibi finansal yükümlülüklerinin karşılanma durumuna bakılarak tespit edilmiştir. Buna ilâveten, yatırımcının kredi riskine sahip olma durumunu anlamak açısından, hanehalkının ev ve otomobil sahiplik durumuna da bakılmıştır. Ayrıca, hanehalkı gelirinin standart sapması hesaplanarak, gelirin yıllar içerisinde ne kadar değişkenlik gösterdiği incelenmiş ve gelir riski değişkeni bulunmuştur. Öncelikle, çalışmada yer alması planlanan değişkenler arasındaki korelasyonlar hesaplanarak bir ön çalışma yapılmıştır. Kurulan modelde hatalı sonuçlara yönlendirmemesi amacıyla, aralarında 
yüksek korelasyon (multicollinearity) bulunan değişkenler veri setinden çıkartılmış, model diğer kalan değişkenler üzerinden analiz edilmiştir.

Tablo 2: Çalışmada Kullanılan Değişkenlerin Pearson Kolerasyon Katsayıları

\begin{tabular}{|c|c|c|c|c|c|c|}
\hline Pearson Korelasyon Katsayıları & $\begin{array}{c}\text { Borç } \\
\text { ödeme }\end{array}$ & $\begin{array}{l}\text { Gelir } \\
\text { riski }\end{array}$ & $\begin{array}{l}\text { Yaş } \\
\text { grubu }\end{array}$ & $\begin{array}{c}\text { Eğitim } \\
\text { seviyesi }\end{array}$ & $\begin{array}{c}\text { Medeni } \\
\text { hâl }\end{array}$ & $\begin{array}{c}\text { Gelir } \\
\text { düzeyi }\end{array}$ \\
\hline Borç ödeme & 1 & & & & & \\
\hline Gelir riski & ,018* & 1 & & & & \\
\hline Yaş grubu & $\begin{array}{c}- \\
179 * *\end{array}$ & $\begin{array}{c}- \\
, 059 * *\end{array}$ & & & & \\
\hline Eğitim seviyesi & ,020* &, $068 * *$ & , $384^{* *}$ & 1 & & \\
\hline Medeni hâl &, $044^{* *}$ &, $057^{* *}$ & $\begin{array}{c}- \\
, 319 * *\end{array}$ & ,236** & 1 & \\
\hline Gelir düzeyi & $\begin{array}{c}- \\
, 080 * *\end{array}$ &, $150 * *$ & $\begin{array}{c}- \\
, 120 * *\end{array}$ &, $515^{* *}$ & ,193** & 1 \\
\hline
\end{tabular}

* Korelasyon 0.05 düzeyinde anlamlı bulunmuştur.

** Korelasyon 0.01 düzeyinde anlamlı bulunmuştur.

Tablo 2'de yer alan bağımsız değişkenler arasındaki korelasyon incelendiğinde, değişkenler arasındaki korelasyonun 0,50'den büyük olmadığı görülmüştür. ("gelir düzeyi" ve "eğitim seviyesi" değişkenleri arasında tespit edilen 0,515 korelasyon değeri, 0,50’ye çok yakın olduğundan istisna olarak düşünülmemiştir.) Bundan dolayı, değişkenlerin birbirlerini etkilemeyecekleri ve aynı modelde yer almalarının herhangi bir sıkıntı doğurmadı̆̆ sonucuna varılmıştır. Yapılan korelasyon analizinden sonra, çalışmada kullanılan değişkenler;

- Borç ödeme,

- Gelir riski,

- Yaş grubu,

- Eğitim seviyesi,

- Medeni hâl,

- Gelir düzeyi olarak belirlenmiştir.

Çalışmada yer alan bağımsız değişkenlerin veri çözümlemeleri, SPSS 20.0 istatistik paket programından yararlanılarak gerçekleştirilmiş, çalışmada toplam 6 değişken kullanılmıştır. Değişkenlere ait kodlar ve açıklamaları aşağıda verilmiştir:

- Değişken 1 = "Borç ödeme"

Açıklama: Son 1 yıl içinde taksit, kredi kartı ve diğer borç ödemelerinin planlandığı gibi ödenememe, borç ödeyememe sorunu yaşama durumu 
Tablo 3: Borç Ödeme Değişkeninin Değerleri

\begin{tabular}{cc}
\hline Value (Değer) & Label (Etiket) \\
\hline $\mathbf{1}$ & Evet oldu \\
$\mathbf{0}$ & Bu tür ödeme yok veya hayır olmadı \\
\hline
\end{tabular}

- Değişken 2 = "Gelir riski"

Açıklama: Toplam hanehalkı kullanılabilir gelirinin standart sapması alınmıştır.

- $\quad$ Değişken 3 = "Eğitim seviyesi"

Açıklama: Ferdin (hanehalkı reisinin) en son bitirdiği okul (En son diploma alınan okul)

Tablo 4: Eğitim Seviyesi Değişkeninin Değerleri

\begin{tabular}{cc}
\hline Value (Değer) & Label (Etiket) \\
\hline $\mathbf{0}$ & Okur- yazar olmayan \\
$\mathbf{1}$ & Okur yazar olup, bir okul bitirmeyen \\
$\mathbf{2}$ & ilkokul \\
$\mathbf{3}$ & Ortaokul, mesleki ortaokul ve ilköğretim \\
$\mathbf{4}$ & Genel lise \\
$\mathbf{5}$ & Mesleki veya teknik lise \\
6 & Yüksekokul, fakülte ve üzeri \\
\hline
\end{tabular}

- Değişken 4 = "Medeni hâl"

Açıklama: Ferdin (hanehalkı reisinin) medeni durumu

Tablo 5. Medeni Hâl Değişkeninin Değerleri

\begin{tabular}{cc}
\hline Value (Değer) & Label (Etiket) \\
\hline $\mathbf{1}$ & Evli \\
$\mathbf{0}$ & Diğerleri \\
\hline
\end{tabular}

- Değişken 5 = "Yaş grubu"

Açıklama: Ferdin (hanehalkı reisinin) ait olduğu yaş grubu 
Tablo 6: Yaş Grubu Değişkeninin Değerleri

\begin{tabular}{cc}
\hline Value (Değer) & Label (Etiket) \\
\hline $\mathbf{4}$ & $15-19$ yaş arası \\
$\mathbf{6}$ & $20-24$ yaş arası \\
$\mathbf{7}$ & $25-29$ yaş arası \\
$\mathbf{8}$ & $30-34$ yaş arası \\
$\mathbf{9}$ & $35-39$ yaş arası \\
$\mathbf{1 0}$ & $40-44$ yaş arası \\
$\mathbf{1 1}$ & $45-49$ yaş arası \\
$\mathbf{1 2}$ & $50-54$ yaş arası \\
$\mathbf{1 3}$ & $55-59$ yaş arası \\
$\mathbf{1 4}$ & $60-64$ yaş arası \\
\hline
\end{tabular}

- Değişken 6 = "Gelir düzeyi"

Açıklama: Toplam hanehalkı kullanılabilir geliri hesaplanarak logaritması alınmıştır.

Çalışmada yer alan değişkenlere ilişkin istatistikî bilgilere, Tablo 7'de yer verilmiştir.

Tablo 7: Betimleyici İstatistik Değerleri

\begin{tabular}{|c|c|c|c|c|c|c|c|}
\hline & Gözlem & Min. & Maks & \multicolumn{2}{|c|}{ Ortalama } & St. Sapma & Varyans \\
\hline $\begin{array}{c}\text { Borç } \\
\text { ödeme }\end{array}$ & 13979 & 0 & 1 & 0,09 & 0,002 & 0,29 & 0,08 \\
\hline $\begin{array}{l}\text { Gelir } \\
\text { riski }\end{array}$ & 13979 & 0 & 11,39 & 8,95 & 0,019 & 2,27 & 5,16 \\
\hline $\begin{array}{c}\text { Yaş } \\
\text { grubu }\end{array}$ & 13979 & 3,03 & 10,85 & 5,13 & 0,012 & 1,39 & 1,93 \\
\hline $\begin{array}{l}\text { Eğitim } \\
\text { seviyesi }\end{array}$ & 13979 & 0 & 6 & 2,62 & 0,015 & 1,72 & 2,97 \\
\hline $\begin{array}{l}\text { Medeni } \\
\text { hâl }\end{array}$ & 13979 & 0 & 1 & 0,83 & 0,003 & 0,37 & 0,14 \\
\hline $\begin{array}{c}\text { Gelir } \\
\text { düzeyi }\end{array}$ & 13979 & 8,05 & 11,73 & 10,26 & 0,002 & 0,29 & 0,08 \\
\hline $\begin{array}{l}\text { Geçerli } \\
\text { Gözlem }\end{array}$ & 13979 & & & & & & \\
\hline
\end{tabular}

\section{Çalışmada Kullanılan Lojistik Regresyon Yöntemi}

Lojistik regresyon yöntemi bir olayın olma olasılığını olmama olasılığıyla karşılaştıran "odds" oranına dayanır (Berenson ve diğerleri, 2004). Lojistik regresyon analizinin kategorik veri analizinde önemli bir yere sahip olmasının nedeni ise, basit ve çoklu regresyon modellerinde sadece sayısal değerler alabilen bağımsız değişkenlerden farklı 
olarak, lojistik regresyonun kategorik değerler alan bağımsız değişkenlere sahip olmasıdır. Standart bir regresyon eşitliği, bağımlı değişkenin değerini öngörmek amacıyla, birkaç bağımsız değişkenin gerçek değerlerinden üretilen ağırlıkları toplamından oluşurken; lojistik regresyon eşitliğinde, tahmin edilen değer " 0 " ile " 1 " arasında değişen bir olasılık değerinden oluşmaktadır. Bir başka deyişle, lojistik regresyon analizi, her bir denek için belirli sonuçların gerçekleşme olasılığını hesaplamaktadır (Çokluk, 2010). Ayrıca, bağımsız değişkenlerin normal dağılması, doğrusallık, varyans-kovaryans matrislerinin eşitliği gibi özel şartları sağlaması gerekmediğinden de, lojistik regresyon diğer tekniklere göre daha esnek bir regresyon çeşididir.

Lojistik regresyon hesabı, odds ve odds'un logaritmalarına dayanmaktadır. Odds oranının hesaplanması, Eşitlik 1'de verilmiştir:

Odds Oranı $=$ Bir olayın olma olasılığı

1- Bir olayın olma olasılığı

Lojistik regresyon modeli, hesaplanan bu odds oranının doğal logaritmasına dayanmaktadır. Eşitlik 2'de, k tane bağımsız değişken için lojistik regresyon modelini tanımlanmaktadır:

$$
\begin{gathered}
\text { In(odds oranı) }=\beta_{0}+\beta_{1} X_{1 i}+\beta_{2} X_{2 i}+\ldots+\beta_{k} X_{k i}+e_{i} \\
k=\text { modeldeki bağımsız değişken sayısı } \\
\text { ei }=\text { i gözlemindeki rassal (tesadüfi) hata }
\end{gathered}
$$

Çokluk (2010), lojistik regresyon analizinin günümüzde yaygın olarak kullanılmasının sebeplerini şöyle açıklamıştır:

- Bağımlı değişken, kategorik (kesikli, süreksiz) olurken; bağımsız değişkenler, sürekli, kategorik ya da ikilem olabilmektedir. Lojistik regresyonda bağımsız değişkenlerin sürekli veya süreksiz olması açısından herhangi bir kısıt bulunmamaktadır.

- Lojistik modelin parametrelerinin yorumlanması kolaydır ve matematiksel olarak da kullanılması kolay olan fonksiyonlar ortaya çıkarmaktadır.

- Lojistik regresyon analizlerini yapmaya imkân sağlayan SPSS, SAS gibi pek çok bilgisayar paket programı mevcuttur.

- Bağımsız değişkenlerin olasılık fonksiyonlarının dağılımı konusunda herhangi bir kısıt bulunmadığı için, çeşitli testlerin uygulanması mümkün olabilmektedir.

- Lojistik regresyonda bütün olasılık değerleri pozitiftir ve değerler 0 ile 1 arasında değişmektedir.

- Lojistik regresyon analizinde, bağımlı ve bağımsız değişken arasındaki ilişkinin doğrusal olması gerekmemektedir. Üstel veya polinom ilişkisi de olabilmektedir. Bunun yanında, lojistik regresyon bağımlı ve bağımsız değişkenler arasında logit bir ilişki olduğu 
varsayımına sahiptir. Bu sebeple, doğrusal olmayan modeller üretebilmekte, değişkenler arasındaki ilişkiyi doğrusal hale getiren logaritmik dönüştürmeler yapmaktadır.

\section{BULGULAR}

Lojistik regresyon analizinde, 13979 katılımcıya ilişkin verilerin tamamı gözlenmiş, herhangi bir kayıp gözlem sözkonusu olmamıştır. Bağımlı değişken olarak tanımlanan "Menkul kıymet yatırımı", menkul kıymet yatırımı yapan yatırımcılar için "1", menkul kıymet yatırımı yapmayan yatırımcılar içinse, "0" olarak kodlanmıştır.

Tablo 8: Hosmer ve Lemeshow Testi

\begin{tabular}{cccc}
\hline Adım & Ki-Kare & Serbestlik & Anlamlılık \\
\hline $\mathbf{1}$ & 3,619 & 8 &, 890
\end{tabular}

Bir sonraki adımda, Tablo 8'de detayları verilen Hosmer ve Lemeshow uyum iyiliği testi yapılmıştır. Elde edilen sonuçlarda, anlamlılık değeri 0,890 olarak bulunmuştur. Bu değerin yüksek bulunması, model ve veri arasındaki uyumun yeterli olduğunu ortaya koymaktadır (Çokluk, 2010). Bu değer, kritik değer olan 0,05'ten büyük olduğundan, borç ödeme, gelir riski, yaş grubu, eğitim seviyesi, medeni hâl ve gelir düzeyi bağımsız değişkenleriyle oluşturulan regresyon modelinin anlamlı bulunduğu ve ayrımın başarıyla yapıldığı sonucuna ulaşılmıştır.

Tablo 9: Model Özeti

\begin{tabular}{cccc}
\hline Adım & -2 Log olasılık & Cox \& Snell R & ${\text { Nagelkerke } \mathrm{R}^{2}}^{2}$ \\
\hline $\mathbf{1}$ & 16620,043 &, 130 &, 177 \\
\hline
\end{tabular}

Tablo 9'da, modele ait Cox \& Snell $R^{2}$ ve Nagelkerke $R^{2}$ değerleri, 0,130 ve 0,177 olarak bulunmuştur. Bir başka deyişle, kurulan lojistik regresyon modelinin kullanılan değişkenleri açıklama oranları sırasıyla, \%13 ve \%17,7'dir.

Tablo 10: Sınıflandırma Tablosu

\begin{tabular}{|c|c|c|c|c|c|}
\hline \multicolumn{3}{|c|}{ Gözlenen } & \multicolumn{3}{|c|}{ Tahmin Edilen } \\
\hline & & & \multicolumn{2}{|c|}{$\begin{array}{c}\text { Menkul Kıymet } \\
\text { Yatırımı }\end{array}$} & \multirow[t]{2}{*}{ Doğruluk Yüzdesi } \\
\hline & & & 0 & 1 & \\
\hline Adım & Menkul Kıymet & 0 & 3220 & 2095 & 60,6 \\
\hline \multirow[t]{2}{*}{1} & Yatırımı & 1 & 2647 & 6017 & 69,4 \\
\hline & Toplam Yüz & & & & 66,1 \\
\hline
\end{tabular}

Kesim değeri: ,600

Tablo 10'daki sınıflandırma tablosu, modelde tahmin edilen değerlerin ne kadarının gerçek gözlenen değerlerle birebir örtüştüğünü ifade etmektedir. Buna göre; menkul kıymet yatırımı yapmayan bir yatırımcının (0), menkul kıymet yatırımı yapmayan bir yatırımcı (0) olarak atanmasında \%60,6 oranında doğruluk sağlanmıştır. Benzer şekilde, menkul kıymet yatırımı yapan bir yatırımcının (1), menkul kıymet yatırımı yapan bir yatırımcı (1) olarak atanmasında \%69,4 oranında bir başarı elde edilmiştir. Modelin genel olarak doğru 
sınıflandırma oranı ise, \%66,1'dir. Bu değerlerin hepsi, modelin sınıflandırma gücünün yeterli olduğunu ortaya koymaktadır.

Daha sonra Tablo 11'de, denklemdeki değişkenlere ilişkin bulgular incelenmiştir ve modelde kullanılması düşünülen bağımsız değişkenlere ait anlamlılık değerlerine bakılarak hangi değişkenlerin model için anlamlı olduğu tespit edilmiştir. Buna göre;

- Borç ödeme,

- Gelir riski,

- Yaş grubu,

- Medeni hâl,

- Gelir düzeyi değişkenlerinin \%99 güvenilirlik düzeyinde model için anlamlı olduğu (0,01 kritik değerinden küçük),

- Eğitim seviyesi değişkeninin ise, \%99 güvenilirlik düzeyinde anlamlı olmadığı $(0,01$ kritik değerinden büyük); ancak \%95 güvenilirlik düzeyinde anlamlı olduğu $(0,05$ kritik değerinden küçük) görülmüştür.

Elde edilen istatistiki bulgular neticesinde, denkleme Tablo 4.4'te belirtilen tüm değişkenler alınmıştır.

Tablo 11: Denklemdeki Değişkenler

\begin{tabular}{|c|c|c|c|c|c|c|}
\hline Değişkenler & Beta & St. Hata & Wald & Serbestlik & Anlamlılık & $\begin{array}{l}\text { Odds } \\
\text { Oranı }\end{array}$ \\
\hline $\begin{array}{l}\text { Borç } \\
\text { ödeme }\end{array}$ &,- 235 & ,065 & 12,932 & 1 & , 000 & 791 \\
\hline Gelir riski & 135 & ,008 & 255,209 & 1 & ,000 & 1,144 \\
\hline Yaş grubu & 322 & ,016 & 410,816 & 1 & ,000 & 1,379 \\
\hline $\begin{array}{l}\text { Eğitim } \\
\text { seviyesi }\end{array}$ & ,032 & ,014 & 5,209 & 1 & ,022 & 1,033 \\
\hline Medeni hâl &,- 260 & ,052 & 24,585 & 1 & ,000 & 771 \\
\hline $\begin{array}{l}\text { Gelir } \\
\text { düzeyi } \\
\text { “log” }\end{array}$ & 2,369 & ,086 & 757,476 & 1 & ,000 & 10,689 \\
\hline Sabit & $\begin{array}{c}- \\
26,430\end{array}$ & ,863 & 937,683 & 1 & ,000 & ,000 \\
\hline
\end{tabular}

Bağımlı Değişken: Menkul kıymet yatırımı

Lojistik regresyon analizi sonucunda, modelin kesim noktasına (sabit) ve bağımsız değişkenlerin katsayılarına ulaşılması ile birlikte, kurulan model aşağıdaki şekilde ifade edilmiştir:

Menkul kıymet yatırımı $=-26,430-0,235 *$ Borç ödeme $+0,135 *$ Gelir riski + $0,322 *$ Yaş grubu $+0,032 *$ Eğitim seviyesi $-0,260 *$ Medeni hâl $+2,369 *$ Gelir düzeyi 
Modelin bağımsız değişkenleri odds oranları dikkate alınarak incelendiğinde, bireysel yatırımcıların menkul kıymet yatırım yapmalarında en fazla etkiye sahip olan değişkenin, oldukça büyük bir oranla "Gelir düzeyi" değişkeni olduğu gözlemlenmiştir. Bu değişkeni, "Medeni hâl" değişkeni izlemektedir. Buna göre, bekâr yatırımcılar evli statüsüne geçtiklerinde, yatırımcının menkul kıymet yatırımı yapma olasılığında \%22,9 [=(1$0,771) * 100]$ oranında azalış ortaya çıkmaktadır. Yatırımcının menkul kıymet yatııımı yapma olasılı̆̆ını en fazla etkileyen bir sonraki değişken ise, "Borç ödeme" değişkenidir. Borç ödeme sorunu olmayan yatırımcılar, borç ödeme sorunu olan yatırımcılar statüsüne geçtiklerinde, yatırımcının menkul kıymet yatırımı yapma olasılığında \%20,9 [=(1$0,791)^{*} 100$ ] oranında azalış tespit edilmiştir.

Modelde yer alan diğer değişkenlerin bireysel yatırımcıların menkul kıymet yatırımı yapma olasılığına olan etkileri incelendiğinde ise;

$\checkmark$ Gelir riskine sahip olan yatırımcıların gelir riskine sahip olmayan yatırımcılara göre,

$\checkmark$ Yaşı büyük olan yatırımcıların yaşı küçük olan yatırımcılara göre,

$\checkmark$ Eğitim seviyesi yüksek olan yatırımcıların eğitim seviyesi düşük olan yatırımcılara göre,

$\checkmark$ Bekâr yatırımcıların evli yatırımcılara göre,

$\checkmark$ Gelir düzeyi yüksek olan yatırımcıların gelir düzeyi düşük olan yatırımcılara göre, risk toleranslarının daha yüksek olduğu ve menkul kıymetlere daha fazla yatırım yaptıkları gözlemlenmiştir.

Bu çalışmada, Wang ve Hanna'nın (1997) yatırımcının yaşının arttıkça riskli varlıklara yapılan yatırımın yüzdesinin arttığını savunan çalışmalarına, Wagner'ın (2011) yaşla birlikte sahip olunan servetin ve tecrübenin yaşça daha büyük olan yatırımcıların risk alarak yatırım yapma potansiyelini arttırdığını ortaya koyan çalışmalarına paralel sonuçlar elde edilmiştir. Buna ilaveten, Bellante ve Gren (2004), Harrison ve diğerleri (2007), Grable (2000), Schooley ve Worden (1999), Brijlal (2007) ve Faff ve diğerleri (2008)'nin literatürde ortaya koyduğu çalışmalar da bu çalışmanın sonuçlarını destekler niteliktedir.

Grable ve Lytton (1999), Sung ve Hanna (1996), Coleman (2003), Grable ve Lytton (2000), Ardehali (2004), Hawley ve Fuji (1993), Sultana ve Pardhasaradhi (2011) ve Grable'ın (1997) literatürde geçen eğitim seviyesinin yatırımcıların risk tolerans düzeylerine ve yatırım kararlarına etkilerini konu alan çalışmalarının sonuçlarına benzer şekilde, bu çalışmada da eğitim seviyesinin arttıkça yatırımcının risk toleransının arttığı ve daha fazla yatırım yaptığı sonucuna ulaşılmıştır. Bunun sebebini, eğitimin yatırımcıya kazandırdı̆̆ı bilgi düzeyi, profesyonellik, değerlendirme ve analiz yetileri olarak göstermek mümkündür.

Medeni hâlin yatırımcının risk toleransı ve yatırım kararları üzerindeki etkisi incelendiğinde ise, Saraç ve Kahyaoğlu'nun (2011) ve Grable ve Lytton (1998)'ın evli yatırımcıların bekâr yatırımcılara oranla, daha çok riskten kaçınmak istediğini ortaya koyan çalışmalarıyla aynı sonuca ulaşılmıştır. Buna göre; Chaulk (1997) ve Riley ve Russon (1995)'ın çalışmalarına paralel olarak evlilikle artan sorumluluğun, riskli yatırımlardan kaynaklı olası kayıpların evli bireylerde yarattığı etkinin ve bakmakla yükümlü olunan birey sayısının sahip olunan çocuklarla birlikte artmasının, evli yatırımcıların bekâr yatırımcılara göre daha az menkul kıymet yatırımı yapmasına neden olduğu söylenebilmektedir. 
Son olarak, gelir düzeyinin (mal varlığının) yatırımcının menkul kıymet yatırımı yapma isteği ile korelasyonuna bakıldığında, bu çalışmada da Finke ve Huston (2003), Huston ve Chang (1997), Grable (1997), Hawley ve Fuji (1993), Watson ve McNaughton (2007) ve Ardehali (2004)'nin çalışmalarının ortaya çıkardığı sonuçlara paralel olarak, yatırımcının gelir düzeyinin arttıkça, aldığı risk miktarının ve yaptığı yatırımların da arttığı sonucuna ulaşılmıştır. Bu da, yatırımcının karşılaştığı olası bir risk tolere edip kayıplarını karşılayabilmek için, diğer yatırımcılara oranla daha fazla servet ve mal varlığına sahip olduğu şeklinde yorumlanabilmektedir.

\section{YÜKSEK EĞITIM VE MENKUL KIYMET YATIRIMLARI}

Önceki bölümlerde açıklandığı gibi, eğitim ile risk alma arasında yüksek düzeyli bir ilişki vardır. Kurduğumuz ilk model de, bu konuda uluslararası literatürü destekleyen sonuçlar vermiştir. Lojistik regresyon analizi kullanılan bu çalışmanın bir sonraki aşamasında daha detaylı bir analiz yapılarak, Türkiye'deki yatırımcıların eğitim seviyesine göre yaptıkları menkul kıymet yatırımları incelenmiştir. Bu amaçla bireysel yatırımcılar, "Üniversite veya daha fazla eğitim alanlar" ve "Lise veya daha az eğitim alanlar" başlıkları altında iki gruba ayrılmıştır. Bu şekilde grupların davranışları ayrı ayrı değerlendirilmiştir.

\section{Üniversite veya Daha Fazla Eğitim Alanlar:}

Üniversite ve daha fazla eğitim alan bireyler için menkul kıymet sahipliği durumu aşağıdaki tabloda verilmiştir.

Tablo 12: Üniversite veya Daha Fazla Eğitim Alanlar İçin Menkul Kıymet Sahipliği Durumu

\begin{tabular}{ccc}
\hline & Sayı & Yüzde \\
\hline Menkul kıymet sahibi & 1219 & $\% 76,47$ \\
Menkul kıymet sahibi değil & 375 & $\% 23,53$ \\
\hline $\begin{array}{c}\text { Analize katılan toplam } \\
\text { birey }\end{array}$ & $\mathbf{1 5 9 4}$ & $\% \mathbf{1 0 0}$ \\
\hline
\end{tabular}

Tablo 12 'de yer alan bilgilere göre, analize katılan kişilerin \%76,47'si menkul kıymet sahibi, $\% 23,53$ 'ü ise menkul kıymet sahibi değildir.

Tablo 13: Hosmer ve Lemeshow Testi (Üniversite veya Daha Fazla Eğitim Alanlar İçin)

\begin{tabular}{cccc}
\hline Adım & Ki-Kare & Serbestlik & Anlamlılık \\
\hline $\mathbf{1}$ & 3,353 & 8 &, 910 \\
\hline
\end{tabular}

Tablo 13'te detayları verilen Hosmer ve Lemeshow uyum iyiliği testi incelendiğinde, anlamlılık değeri 0,910 olarak bulunmuştur. Bu değer, kritik değer olan 0,05'ten büyük olduğundan borç ödeme, gelir riski, yaş grubu, eğitim seviyesi, medeni hâl ve gelir düzeyi bağımsız değişkenleriyle oluşturulan regresyon modelinin anlamlı bulunduğu ve ayrımın başarıyla yapıldığı sonucuna ulaşılmıştır.

Tablo 14: Model Özeti (Üniversite veya Daha Fazla Eğitim Alanlar İçin)

\begin{tabular}{cccc}
\hline Adım & -2 Log olasılık & Cox \& Snell $\mathrm{R}^{2}$ & ${\text { Nagelkerke } \mathrm{R}^{2}}^{2}$ \\
\hline $\mathbf{1}$ & 1497,281 &, 141 &, 212 \\
\hline
\end{tabular}


Tablo 14'te, modele ait Cox \& Snell $R^{2}$ ve Nagelkerke $R^{2}$ değerleri, 0,141 ve 0,212 olarak bulunmuştur. Bir başka deyişle, kurulan lojistik regresyon modelinin kullanılan değişkenleri açıklama oranları sırasıyla, \%14,1 ve \%21,2'dir.

Tablo 15: Sınıflandırma Tablosu (Üniversite veya Daha Fazla Eğitim Alanlar İçin)

\begin{tabular}{|c|c|c|c|c|c|}
\hline \multicolumn{3}{|c|}{ Gözlenen } & \multicolumn{3}{|c|}{ Tahmin Edilen } \\
\hline & & & \multicolumn{2}{|c|}{$\begin{array}{c}\text { Menkul Kıymet } \\
\text { Yatırımı }\end{array}$} & \multirow[t]{2}{*}{ Doğruluk Yüzdesi } \\
\hline & & & 0 & 1 & \\
\hline Adım & Menkul Kıymet & 0 & 250 & 125 & 66,7 \\
\hline \multirow[t]{2}{*}{1} & Yatırımı & 1 & 383 & 836 & 68,6 \\
\hline & Toplam Yü & & & & 68,1 \\
\hline
\end{tabular}

Kesim değeri: ,750

Tablo 15'te yer alan sınıflandırma tablosu değerlerine göre; menkul kıymet yatırımı yapmayan üniversite ve daha fazla eğitim almış bir yatırımcının (0), menkul kıymet yatırımı yapmayan üniversite ve daha fazla eğitim almış bir yatırımcı (0) olarak atanmasında \%66,7 oranında doğruluk sağlanmıştır. Benzer şekilde, menkul kıymet yatırımı yapan üniversite ve daha fazla eğitim almış bir yatırımcının (1), menkul kıymet yatırımı yapan üniversite ve daha fazla eğitim almış bir yatırımcı (1) olarak atanmasında \%68,6 oranında bir başarı elde edilmiştir. Modelin genel olarak doğru sınıflandırma oranı ise, \%68,1'dir. Bu değerler, modelin sınıflandırma gücünün yeterli olduğunu ortaya koymaktadır. Ayrıca, verilerin tamamı ele alınarak gerçekleştirilen ilk analize oranla da üniversite ve daha fazla eğitim alan bireylerin analizinde modelin doğru sınıflandırma gücü daha yüksek bulunmuştur.

Tablo 16'da, denklemdeki değişkenlere ilişkin bulgular incelenip, modelde kullanılması düşünülen bağımsız değişkenlere ait anlamlılık değerlerine bakıldığında ise, çalışmanın ilk analizinden daha farklı sonuçlar elde edilmiştir;

- Gelir riski,

- Yaş grubu,

- Gelir düzeyi değişkenlerinin \%99 güvenilirlik düzeyinde model için anlamlı olduğu (0,01 kritik değerinden küçük),

o Borç ödeme,

o Eğitim seviyesi,

o Medeni hâl değişkenlerinin ise, \%99 güvenilirlik düzeyinde de, \%95 güvenilirlik düzeyinde de anlamlı olmadığı $(0,01$ ve 0,05 kritik değerlerinden büyük) görülmüştür.

Buna göre; üniversite ve daha fazla eğitim alan bireyler için; borç ödeme, eğitim seviyesi (üniversite ve üzeri) ve medeni hâl değişkenlerinin bireyin menkul kıymet yatırımı yapması üzerinde önemli bir etkisi olmadığı sonucuna ulaşılmıştır.

Tablo 16: Denklemdeki Değişkenler (Üniversite veya Daha Fazla Eğitim Alanlar İçin)

\begin{tabular}{lcccccc}
\hline Değişkenler & Beta & $\begin{array}{c}\text { St. } \\
\text { Hata }\end{array}$ & Wald & Serbestlik & Anlamlılık & $\begin{array}{l}\text { Odds } \\
\text { Oranı }\end{array}$ \\
\hline $\begin{array}{l}\text { Borç } \\
\text { ödeme }\end{array}$ &,- 153 &, 276 &, 308 & 1 &, 579 &, 858 \\
\hline
\end{tabular}




\begin{tabular}{|c|c|c|c|c|c|c|}
\hline Gelir riski & ,089 & ,025 & 12,492 & 1 & ,000 & 1,093 \\
\hline Yaş grubu & ,438 & ,063 & 48,423 & 1 & ,000 & 1,550 \\
\hline $\begin{array}{l}\text { Eğitim } \\
\text { seviyesi }\end{array}$ & ,328 & ,838 & ,153 & 1 & ,695 & 1,388 \\
\hline Medeni hâl &,- 051 & 198 & ,065 & 1 & 798 & 951 \\
\hline $\begin{array}{l}\text { Gelir } \\
\text { düzeyi } \\
\text { "log" }\end{array}$ & 3,716 & ,336 & 122,436 & 1 & ,000 & 41,086 \\
\hline Sabit & $\begin{array}{c}- \\
42,509 \\
\end{array}$ & 5,918 & 51,599 & 1 & ,000 & ,000 \\
\hline
\end{tabular}

Bağımlı Değişken: Menkul kıymet yatırımı

Lojistik regresyon analizi sonucunda, modelin kesim noktasına (sabit) ve bağımsız değişkenlerin katsayılarına ulaşılması ile birlikte kurulan model aşağıdaki şekilde ifade edilmiştir:

Menkul kıymet yatırımı (Üniversite veya daha fazla eğitim alanlar) $=-42,509$ $0,153 *$ Borç ödeme $+0,089 *$ Gelir riski $+0,438 *$ Yaş grubu $+0,328 *$ Eğitim seviyesi $0,051 *$ Medeni hâl $+3,716 *$ Gelir düzeyi

\section{Lise veya Daha Az Eğitim Alanlar}

Lise veya daha az eğitim alan bireyler için menkul kıymet sahipliği durumu aşağıdaki tabloda verilmiştir.

Tablo 17: Lise veya Daha Az Eğitim Alanlar İçin Menkul Kıymet Sahipliği Durumu

\begin{tabular}{ccc}
\hline & Sayı & Yüzde \\
\hline Menkul kıymet sahibi & 7445 & $\% 60,11$ \\
$\begin{array}{c}\text { Menkul kıymet sahibi } \\
\text { değil }\end{array}$ & 4940 & $\% 39,89$ \\
\hline $\begin{array}{c}\text { Analize katılan toplam } \\
\text { birey }\end{array}$ & $\mathbf{1 2 3 8 5}$ & \% 100 \\
\hline
\end{tabular}

Tablo 17 'de yer alan bilgilere göre, analize katılan kişilerin \%60,11'i menkul kıymet sahibi, $\% 39,89$ 'u ise menkul kıymet sahibi değildir.

Tablo 18: Hosmer ve Lemeshow Testi (Lise veya Daha Az Eğitim Alanlar İçin)

\begin{tabular}{cccc}
\hline Adım & Ki-Kare & Serbestlik & Anlamlılık \\
\hline $\mathbf{1}$ & 5,938 & 8 &, 654 \\
\hline
\end{tabular}

Tablo 18 'de detayları verilen Hosmer ve Lemeshow uyum iyiliği testi incelendiğinde, anlamlılık değeri 0,654 olarak bulunmuştur. Bu değer, kritik değer olan 0,05'ten büyük olduğundan borç ödeme, gelir riski, yaş grubu, eğitim seviyesi, medeni hâl ve gelir düzeyi bağımsız değişkenleriyle oluşturulan regresyon modelinin anlamlı bulunduğu ve ayrımın başarıyla yapıldığı sonucuna ulaşılmıştır. 
Tablo 19: Model Özeti (Lise veya Daha Az Eğitim Alanlar İçin)

\begin{tabular}{cccc}
\hline Adım & -2 Log olasılık & Cox \& Snell $\mathrm{R}^{2}$ & ${\text { Nagelkerke } \mathrm{R}^{2}}^{2}$ \\
\hline $\mathbf{1}$ & 15093,336 &, 119 &, 161 \\
\hline
\end{tabular}

Tablo 19 'da modele ait Cox \& Snell $R^{2}$ ve Nagelkerke $R^{2}$ değerleri, 0,119 ve 0,161 olarak bulunmuştur. Bir başka deyişle, kurulan lojistik regresyon modelinin kullanılan değişkenleri açıklama oranları sırasıyla, \%11,9 ve \%16,1'dir.

Tablo 20: Sınıflandırma Tablosu (Lise veya Daha Az Eğitim Alanlar İçin)

\begin{tabular}{|c|c|c|c|c|c|}
\hline \multicolumn{3}{|c|}{ Gözlenen } & \multicolumn{3}{|c|}{ Tahmin Edilen } \\
\hline & & & \multicolumn{2}{|c|}{$\begin{array}{c}\text { Menkul Kıymet } \\
\text { Yatırımı }\end{array}$} & \multirow[t]{2}{*}{ Doğruluk Yüzdesi } \\
\hline & & & 0 & 1 & \\
\hline \multirow{3}{*}{$\underset{1}{\text { Adım }}$} & \multirow{2}{*}{$\begin{array}{c}\text { Menkul Kıymet } \\
\text { Yatırımı }\end{array}$} & 0 & 3130 & 1810 & 63,4 \\
\hline & & 1 & 2556 & 4889 & 65,7 \\
\hline & \multicolumn{2}{|c|}{ Toplam Yüzde } & & & 64,7 \\
\hline
\end{tabular}

Kesim değeri: ,600

Tablo 20'de yer alan sınıflandırma tablosu değerlerine göre; menkul kıymet yatırımı yapmayan lise ve daha az eğitim almış bir yatırımcının (0), menkul kıymet yatırımı yapmayan lise ve daha az eğitim almış bir yatırımcı (0) olarak atanmasında \%63,4 oranında doğruluk sağlanmıştır. Benzer şekilde, menkul kıymet yatırımı yapan lise ve daha az eğitim almış bir yatırımcının (1), menkul kıymet yatırımı yapan lise ve daha az eğitim almış bir yatırımcı (1) olarak atanmasında \%65,7 oranında bir başarı elde edilmiştir. Modelin genel olarak doğru sınıflandırma oranı ise, $\% 64,7$ 'dir. Bu değerler, modelin sınıflandırma gücünün yeterli olduğunu ortaya koymaktadır. Ancak; verilerin tamamı ele alınarak gerçekleştirilen ilk analize oranla, lise ve daha az eğitim alan bireylerin analizinde modelin doğru sınıflandırma gücünün daha düşük olduğu görülmektedir.

Tablo 21'de denklemdeki değişkenlere ilişkin bulgular incelenip, modelde kullanılması düşünülen bağımsız değişkenlere ait anlamlılık değerlerine bakıldığında ise, çalışmanın ilk analizine tek bir farklılıkla benzer sonuçlar elde edilmiştir;

Borç ödeme,

Gelir riski,

$>$ Yaş grubu,

Medeni hâl,

- Gelir düzeyi değişkenlerinin \%99 güvenilirlik düzeyinde model için anlamlı olduğu (0,01 kritik değerinden küçük),

$>$ Eğitim seviyesi değişkeninin ise, \%99 güvenilirlik düzeyinde de, \%95 güvenilirlik düzeyinde de anlamlı olmadığı (0,01 ve 0,05 kritik değerlerinden büyük) görülmüştür. 
Tablo 21: Denklemdeki Değişkenler (Lise veya Daha Az Eğitim Alanlar İçin)

\begin{tabular}{lcccccc}
\hline Değişkenler & Beta & St. Hata & Wald & Serbestlik & Anlamlılık & $\begin{array}{c}\text { Odds } \\
\text { Oranı }\end{array}$ \\
\hline $\begin{array}{l}\text { Borç } \\
\text { ödeme }\end{array}$ &,- 241 &, 067 & 12,837 & 1 &, 000 &, 786 \\
$\begin{array}{l}\text { Gelir riski } \\
\text { Yaş grubu }\end{array}$ &, 141 &, 009 & 242,929 & 1 &, 000 & 1,152 \\
$\begin{array}{l}\text { Eğitim } \\
\text { seviyesi }\end{array}$ &, 026 &, 017 & 359,318 & 1 &, 000 & 1,370 \\
$\begin{array}{l}\text { Medeni hâl } \\
\text { Gelir }\end{array}$ &,- 278 &, 055 & 25,559 & 1 &, $\mathbf{0 0 0}$ &, 757 \\
$\begin{array}{l}\text { düzeyi } \\
\text { “log” }\end{array}$ & 2,252 &, 089 & 633,665 & 1 &, 000 & 9,509 \\
Sabit & $-25,247$ &, 898 & 789,613 & 1 &, 000 &, 000 \\
\hline
\end{tabular}

Bağımlı Değişken: Menkul kıymet yatırımı

Lojistik regresyon analizi sonucunda, modelin kesim noktasına (sabit) ve bağımsız değişkenlerin katsayılarına ulaşılması ile birlikte kurulan model aşağıdaki şekilde ifade edilmiştir:

Menkul kıymet yatırımı (Lise veya daha az eğitim alanlar) $=-25,247$ $0,241 *$ Borç ödeme $+0,141 *$ Gelir riski $+0,315 *$ Yaş grubu $+0,026 *$ Eğitim seviyesi $-0,278 *$ Medeni hâl $+2,252 *$ Gelir düzeyi

Tablo 22'de yapılan analizler sonucu elde edilen bulguların genel bir özeti verilmiştir. Veri setindeki tüm bireylere, üniversite ve daha fazla eğitim alan bireylere, lise ve daha az eğitim alan bireylere uygulayan lojistik regresyon analizinin sonuçları Tablo 5.11'de yer almaktadır.

\begin{tabular}{|c|c|c|c|c|c|}
\hline & $\begin{array}{c}\text { Modelin } \\
\text { Anlamlılık } \\
\text { Durumu }\end{array}$ & $\begin{array}{c}\text { Istatistiksel } \\
\text { Olarak } \\
\text { Anlamlı } \\
\text { Bulunan } \\
\text { Değişkenler } \\
\end{array}$ & $\begin{array}{c}\text { Istatistiksel } \\
\text { Olarak } \\
\text { Anlamlı } \\
\text { Bulunmayan } \\
\text { Değişkenler }\end{array}$ & $\begin{array}{c}\text { Modeldeki } \\
\text { Değişkenlerin } \\
\text { Açıklama } \\
\text { Oranı }\end{array}$ & $\begin{array}{c}\text { Modelin } \\
\text { Doğru } \\
\text { Sınıflandırma } \\
\text { Oranı }\end{array}$ \\
\hline $\begin{array}{l}\text { Tüm } \\
\text { Bireyler }\end{array}$ & Anlamlı & $\begin{array}{c}\text { Borç } \\
\text { ödeme } \\
\text { Gelir riski } \\
\text { Yaş grubu } \\
\text { Eğitim } \\
\text { seviyesi } \\
\text { Medeni hâl } \\
\text { Gelir } \\
\text { düzeyi }\end{array}$ & - & $\% 17,7$ & $\% 66,1$ \\
\hline
\end{tabular}




\begin{tabular}{|c|c|c|c|c|c|}
\hline \multirow{2}{*}{$\begin{array}{l}\text { Üniversite } \\
\text { ve Daha } \\
\text { Fazla } \\
\text { Eğitim } \\
\text { Alanlar }\end{array}$} & & \multirow{2}{*}{$\begin{array}{c}\text { Gelir riski } \\
\text { Yaş grubu } \\
\text { Gelir } \\
\text { düzeyi }\end{array}$} & \multirow{2}{*}{$\begin{array}{l}\text { Borç ödeme } \\
\text { Eğitim } \\
\text { seviyesi } \\
\text { Medeni hâl }\end{array}$} & \multirow[b]{2}{*}{$\% 21,2$} & \multirow[b]{2}{*}{$\% 68,1$} \\
\hline & Anlamlı & & & & \\
\hline & & $\begin{array}{c}\text { Borç } \\
\text { ödeme }\end{array}$ & & & \\
\hline \multirow{4}{*}{$\begin{array}{l}\text { Lise ve } \\
\text { Daha Az } \\
\text { Eğitim } \\
\text { Alanlar }\end{array}$} & Anlamlı & Gelir riski & Eğitim & $\% 16,1$ & $\% 64,7$ \\
\hline & & Yaş grubu & seviyesi & & \\
\hline & & Medeni hâl & & & \\
\hline & & $\begin{array}{c}\text { Gelir } \\
\text { düzeyi }\end{array}$ & & & \\
\hline
\end{tabular}

Tablo 22. Lojistik Regresyon Analizleri Özeti

\section{SONUÇ}

Her ne kadar geleneksel portföy teorileri, yatırımcıları duygularının etkisi altında kalmadan kararlar verebilen ve sadece getirilerini maksimum düzeye çıkartmak amacıyla hareket eden rasyonel bireyler olarak kabul etseler de, son yıllarda özellikle davranışsal finans alanında yapılan çalışmalar bunun aksini ispatlayarak, insanların karar verme aşamasında sınırsız rasyonellikten sıyrıldığını ortaya çıkarmıştır. Bu çalışmalar ışığında, bireylerin yatırım kararı alırken pek çok psikolojik, bilişsel, demografik ve sosyo-ekonomik faktörlerin etkisi altında kaldığı sonucuna ulaşılmıştır. Günümüze kadar yatırımcı profilini inceleme amacıyla yapılan tüm çalışmalar, yatırımcıların risk tolerans düzeylerinin cinsiyet, yaş grubu, eğitim seviyesi, medeni hâl, meslek grubu, gelir düzeyi, mal varlığı gibi demografik ve sosyo-ekonomik faktörlerle ilişkili olduğunu ve bu faktörlerin de bireyin yatırım kararlarını ciddi ölçüde etkilediğini ispatlamıştır.

Bu çalışmada, Türkiye'de menkul kıymete yatırım yapan bireysel yatırımcıların demografik ve sosyo-ekonomik özelliklerinin tespit edilmesi amacıyla, Tüik'ten temin edilen Gelir ve Yaşam Koşulları Anketi'nin 2009-2012 yılları arasındaki 4 yıllık verileri analiz edilerek bir model geliştirilmiştir. Çalışmada, bireysel yatırımcıların risk toleranslarını etkileyen faktörler literatürde bu konuda yapılan çalışmalar ışığında ele alınarak, yatırımcıların kişisel, psikolojik, demografik ve sosyo-ekonomik birtakım özelliklerinin risk tolerans düzeylerini ve yatırım kararlarını etkilediği varsayılmıştır.

Çalışmada, Türkiye'de menkul kıymete yatırım yapan bireysel yatırımcıların risk tolerans düzeyleri ve yatırım kararları; menkul kıymet yatırımcılarının borç ödeme sorunu yaşama durumları, gelir riski taşıma durumları, eğitim seviyeleri, yaş grupları, medeni hâlleri ve gelir düzeyleri dikkate alınarak analiz edilmiştir.

Çalışmada, kategorik veri analizinde önemli bir yere sahip olması ve basit ve çoklu regresyon analizlerinden farklı olarak, doğrusal olmayan modeller de üretebilmesi sebebiyle lojistik regresyon yönteminin kullanılmasına karar verilmiş, tüm veri setinde ele alınan değişkenler bu yöntemle incelenmiştir. Analiz sonuçlarında, "borç ödeme" ve "medeni hâl" değişkenlerinin yatırımcıların risk toleransına negatif yönde, diğer değişkenlerden "gelir riski", "eğitim seviyesi", "yaş grubu" ve "gelir düzeyi" değişkenlerinin 
ise pozitif yönde etkilediği görülmüştür. Tüm veri setindeki bireyler üzerinde yapılan bu analizlerde, şu sonuçlara ulaşılmıştır:

- Daha yaşlı olan bireyler daha fazla risk almakta ve menkul kıymet yatırımı yapmaktadır.

- $\quad$ Eğitim seviyesi daha yüksek olanlar daha fazla risk almakta ve menkul kıymet yatırımı yapmaktadır.

- Bekâr yatırımcılar evli yatırımcılara göre daha fazla risk almakta ve menkul kıymet yatırımı yapmaktadır.

- Geliri daha yüksek, yüksek gelir grubuna dahil olanlar daha fazla risk almakta ve menkul kıymet yatırımı yapmaktadır.

- $\quad$ Borç ödeme sorunu olmayan bireyler daha fazla risk almakta ve menkul kıymet yatırımı yapmaktadır.

- Gelir riski olan, gelir oynaklığına sahip bireyler daha fazla risk almakta ve menkul kıymet yatırımı yapmaktadır.

Çalışmadaki analizin ikinci kısmında, ana veri seti lojistik regresyon yöntemi ile eğitim seviyelerine göre iki alt grupta incelenmiş, veri setindeki bireyler "üniversite veya daha fazla eğitim alanlar" ve "lise veya daha az eğitim alanlar" olarak iki başlık altında toplanmıştır. Risk tolerans düzeyleri ve menkul kıymet yatırımı yapma kararlarında da gruplar arasında farklılıklar gözlemlenmiştir.

Üniversite veya daha fazla eğitim alan bireyler arasında; gelir riski taşıyanların gelir riski taşımayanlara, yaşı büyük olanların yaşı küçük olanlara, gelir düzeyi yüksek olanların gelir düzeyleri düşük olanlara göre daha fazla menkul kıymet yatırımı yaptıkları, bir başka deyişle, risk tolerans düzeylerinin daha yüksek olduğu görülmüştür. Bununla birlikte, bireyin gelir riski yaşamasının menkul kıymet yatırımı yapması üzerine olumlu bir etkisi olduğu tespit edilmiştir. Ayrıca, analiz sonucunda, bireyin borç ödeme sorunu yaşama durumu, eğitim seviyesi ve medeni hâlinin menkul kıymet yatırımı yapması üzerinde etkili olmadığı sonucuna ulaşılmıştır. Veri setindeki tüm bireylerin ele alınarak yapıldığı analize göre, bu analizde; bireyin menkul kıymet yatırımı yapmasında "gelir riski" değişkeninin etkisi azalırken, en başta "gelir düzeyi" değişkeni olmak üzere "gelir düzeyi" ve "yaş grubu" değişkenlerinin etkisinde artış gözlemlenmiştir.

Lise veya daha az eğitim alan bireyler arasında; borç ödeme sorunu yaşayanların borç ödeme sorunu yaşamayanlara, gelir riski taşıyanların gelir riski taşımayanlara, yaşı büyük olanların yaşı küçük olanlara, bekâr olanların evli olanlara ve geliri yüksek olanların geliri düşük olanlara göre daha fazla menkul kıymet yatırımı yaptıkları, bir başka deyişle, risk tolerans düzeylerinin daha yüksek olduğu görülmüştür. Buna ilaveten, bireyin borç ödeme sorunu yaşamasının menkul kıymet yatırımı yapması üzerinde olumsuz, gelir riskine sahip olmasının ise olumlu etkisi olduğu tespit edilmiştir. Ayrıca analiz sonucunda, bireyin eğitim seviyesinin menkul kıymet yatırımı yapması üzerinde etkili olmadığı ortaya konulmuştur. Veri setindeki tüm bireylerin ele alınarak yapıldığı analize göre, bu analizde; bireyin menkul kıymet yatırımı yapmasında "borç ödeme", "yaş grubu", "medeni hal" ve "gelir düzeyi" değişkenlerinin etkisi azalırken, "gelir riski" değişkeninin etkisinde artış gözlemlenmiştir.

Yapılan tüm lojistik regresyon analizlerinde, "gelir riski", "yaş grubu" ve "gelir düzeyi" bağımsız değişkenlerinin, kurulan modellerin hepsinde önemli bulunduğu görülmüştür. Ayrıca, menkul kıymet yatırımcılarının eğitim seviyelerine göre ayrı veri setlerinde 
incelenmesi sonucunda, eğitim seviyesindeki değişikliklerin bazı değişkenlerin menkul kıymet yatııımı yapma üzerindeki etkisini arttırdığından ve azalttığından bahsetmek mümkün olmuştur. Eğitim seviyesi üniversite veya daha üzerine çıktığında, "yaş grubu" ve "gelir düzeyi" değişkenleri, bireyin menkul kıymet yatırımı yapması üzerindeki etkisini arttırmakta, eğitim seviyesi lise veya daha aşağısına indiğinde ise, "yaş grubu" ve "gelir düzeyi" değişkenleri, bireyin menkul kıymet yatırımı yapması üzerindeki etkisini azaltmaktadır.

Çalışmada kullanılan "borç ödeme", "gelir riski”, "yaş grubu”, "eğitim seviyesi”, "medeni hâl" ve "gelir düzeyi" bağımsız değişkenlerinin, bireylerin menkul kıymet yatırımı yapmalarının yaklaşık olarak \%18'ini açıkladığı görülmüştür. Çalışmada, bireyin menkul kıymet yatırımı yapması üzerinde önemli etkileri olduğu düşünülen değişkenlerden cinsiyet, meslek grubu, yaşanılan bölge, hanehalkının ev ve otomobil sahipliği değişkenleri aralarında yüksek korelasyon (multicollinearity) bulunması sebebiyle, analizde yer almamıştır. Buna ilaveten, veri setindeki bilgilerden bireyin risk toleransı ve yatırım yapma kararı üzerinde etkili olan faktörlerden yatırımcının kişiliği ve etkisi altında olduğu psikolojik faktörlere ulaşmak mümkün olmamıştır. Tüm bu faktörlerin de analize dahil edildiğinde, bireylerin menkul kıymet yatırım kararlarının çok büyük bir bölümünün açıklanacağı düşünülmektedir. Çalışma, menkul kıymet yatırımına etki eden tüm demografik ve sosyo-ekonomik faktörleri modele dahil edememe sınırlılığına sahip olsa da, Türkiye'de menkul kıymete yatırım yapan bireysel yatırımcıların risk tolerans düzeylerine ve buna bağlı olarak yatırım kararlarına etki eden demografik ve sosyo-ekonomik faktörlerin, geniş bir veri seti ele alınarak araştırılması anlamında yapılan bir çalışma olması ve pek çok çalışmadan farklı olarak, yatırımcılara risk eğilimlerini ölçen sorular sormaktan ziyade, yatırımcıların risk tolerans düzeylerini gerçek davranışları (menkul kıymet yatıııı yapma/yapmama) üzerinden açıklaması bakımından, literatüre katkı sağlayacağı ve bundan sonra yapılacak olan daha kapsamlı çalışmalara yol gösterici bir niteliğe sahip olduğu düşünülmektedir.

Sonuç olarak; son yıllarda yükselişe geçen davranışsal finans kavramı, geleneksel finans teorilerinin varsayımlarından farklı olarak bilişsel, psikolojik, demografik ve sosyoekonomik özelliklerin bireylerin risk algılarını, riske karşı tutumlarını ve aldıkları yatırım kararlarını önemli ölçüde etkilediğini ortaya koymuştur. Türkiye'de finansal araçların çeşitlilik kazanmasıyla birlikte, farklı risk ve getiri beklentileri olan yatırımcı profillerine hitap etmeye başlanılması ve menkul kıymete yapılan yatırımların da artmasıyla, bireysel yatırımcıların özelliklerinin araştırılması konusundaki çalışmalar önem kazanmıştır. Bu bakımdan, yatırımcı profilini incelemeye yönelik olarak yapılan çalışmaların başta banka ve finans kuruluşları olmak üzere, finansal yatırım araçları ihraç eden tüm kurumlarca daha da önem kazanacağı öngörülmektedir.

\section{KAYNAKLAR}

Anbar, A., \& Eker, M. (2009). Bireysel Yatırımcıların Finansal Risk Algılamalarını Etkileyen Demografik ve Sosyoekonomik Faktörler. Zonguldak Karaelmas Üniversitesi Sosyal Bilimler Dergisi, 5(9), 129-150.

Antonites, A.J., \& Wordsworth, R. (2009). Risk Tolerance: A Perspective on Entrepreneurship Education. Southern African Business Review, 13 (3). 
Ardehali, P.H. (2004). Assessing Financial Risk Tolerance of Portfolio Investors Using Data Envelopment Analysis. Master's Thesis, Canada.

Arslan, Ö., \& Karan, M.B. (2010). Consumer Credit Risk Characteristics: Understanding Income and Expense Differentials. Emerging Markets Finance and Trade, 46(2), 20-37.

Bajtelsmit, V. L., \& Bernasek, A. (1996). Why Do Women Invest Differently Than Men? Financial Counseling and Planning, 7, 1-10.

Barber, B., \& Odean, T. (2001). Boys Will Be Boys: Gender, Overconfidence, and Common Stock Investment, Quarterly Journal of Economics, 261-292.

Bellante, D., \& Gren, C.A. (2004) Relative Risk Aversion among the Elderly. Review of Financial Economics, 13, 269-281.

Berenson, M. L., Levine, D.M., \& Krehbiel, T.C. (2004). Basic Business Statistics Concepts and Applications, New Jersey: Pearson International Edition.

Brijlal, P. (2007). Key Changes in Profile and Characteristics of Individual Investors on the Johannesburg Securities Exchange (JSE) Over the Past Two Decades. African Journal of Business Management, 1(6), 136-141.

Brown, S., \& Dietrich, M., Ortiz, A, \& Taylor, K. (2007). Self-Employment and Risk Preference. Sheffield Economic Research Paper Series, 1-29.

Chaulk, B. J. (1997). Effects of Marriage and Children on Financial Risk Tolerance. University of British Columbia.

Coleman, S. (2003). Women and Risk: An Analysis of Attitudes and Investment Behavior. Academy of Accounting and Financial Studies Journal, 7(2), 99-122.

Çokluk, Ö. (2010). Lojistik Regresyon Analizi: Kavram ve Uygulama. Kavram ve Uygulamada Eğitim Bilimleri, 10(3), 1357-1407.

Embrey, L.L, \& Fox, J.J. (1997). Gender Differences in the Investment Decision-Making Process. Financial Counseling and Planning, 8(2), 33-40.

Faff, R., Mulino, D., \& Chai, D. (2008). On the Linkage Between Financial Risk Tolerance and Risk Aversion, Journal of Financial Research, 31 (1), 1-23.

Faff, R.W., Hallahan T.A., \& McKenzie, M. (2011). Women and Risk Tolerance in an Aging World. International Journal of Accounting and Information Management, 19(2), 100-117.

Grable, J. E. (1997). Investor Risk Tolerance: Testing the Efficacy of Demographics as Differentiating and Classifying Factors, PhD Thesis, Virginia.

Grable, J. E. (2000). Financial Risk Tolerance and Additional Factors Which Affect Risk Taking in Everyday Money Matters. Journal of Business and Psychology, 14 (4), 625-630.

Grable, J. E. (2008). RiskCAT: A Framework for Identifying Maximum Risk Thresholds in Personal Portfolios. Journal of Financial Planning, 21 (10), 52-62.

Grable, J. E., \& Joo, S. (1997). Determinants of Risk Preference: Implications for Family and Consumer Science Professionals. Family Economics and Resource Management Biennial, 2, 19-24.

Grable, J. E., \& Joo, S. (1999). How to Improve Financial Knowledge, Attitudes, and Behaviors Among Consumer Science Constituencies. The Journal of Consumer Education, 17, 20-26.

Grable, J. E., \& Lytton, R. H. (1998). Investor Risk Tolerance: Testing the Efficacy of Demographics as Differentiating and Classifying Factors. Financial Counseling and Planning, 9, 61-74.

Grable, J. E., \& Lytton, R. H. (1999). Financial Risk Tolerance Revisited: The Development of a Risk Assessment Instrument. Financial Services Review, 8 (3), 163-181.

Grable, J. E., \& Lytton, R.H., O’neill, B., Joo, S.H., \& Klock, D. (2006). Risk Tolerance, Projection Bias, Vividness and Equity Prices. Journal of Investing, 15(2), 68-74.

Haliassos, C., \& Bertaut, M. (1995). Why Do So Few Hold Stocks?. The Economic Journal, 105, 1110-1129. 
Hallahan T.A., Faff, R.W., \& McKenzie, M. (2003). An Exploratory Investigation of the Relation Between Risk Tolerance Scores and Demographic Characteristics. Elsevier, Journal of Multinational Financial Management, 13, 4-5, 483-502.

Harrison, G.W., Lau, M.I., \& Rutstrom, E.E. (2007). Estimating Risk Attitudes in Denmark: A Field Experiment. Scandinavian Journal of Economics, 109(2), 341-368.

Hawley, C.B., \& Fuji, E.T. (1993). An Empirical Analysis of Preferences for Financial Risk: Further Evidence on the Friedman-Savage Model. Journal of Post Keynesian Economics, 16(2), 197-204.

Huston, S. J., \& Chang, Y. R. (1997). Adequate Emergency Fund Holdings and Household Type. Financial Counseling and Planning, 8(1), 37-46.

Kahneman D.,\& Tversky A. (1979). Prospect Theory: An Analysis of Decision Under Risk, Econometrica, 47(2), 263-292.

Maxfield, S., Shapiro, M., Gupta, V., \& Hass, S. (2010). Gender and Risk: Women, Risk Taking and Risk Aversion. Gender in Management: An International Journal, 25(7), 586 - 604.

Morin, R. A.,\& Suarez, A. F. (1983). Risk Aversion Revisited. The Journal of Finance, 38(4), 1201-1216.

Nelson, J.A. (2012). Are Women Really More Risk-Averse than Men? Global Development and Environment Institute Working Paper,5.

Riley, N. F., \& Russon, M. G. (1995). Individual Asset Allocation and Indicators of Perceived Client Risk Tolerance, Journal of Financial and Strategic Decisions, 8(1), 65-70.

Roszkowski, M. J., Davey, G., \& Grable, J. E. (2005). Insights on Measuring Risk Tolerance From Psychology and Psychometrics. Journal of Financial Planning, 18(4), 68-76.

Saraç, M., \& Kahyaoğlu, M. B. (2011). Bireysel Yatıımcıların Risk Alma Eğilimine Etki Eden Sosyo-Ekonomik ve Demografik Faktörlerin Analizi, BDDK Bankacılık ve Finansal Piyasalar, 5(2), 135-157.

Schooley, D.K.,\& Worden, D.D. (1999). Investors' Asset Allocations versus Life-Cycle Funds. Financial Analysts Journal, 55(5), 37-43.

Schubert, R., Gysler M., Brown M., \& Brachinger H. W. (2000). Gender Specific Attitudes Towards Risk and Ambiguity: An Experimental Investigation. Working Paper, Center for Economic Research, Swiss Federal Institute of Technology, Zurich.

Sultana, S. T., \& Pardhasaradhi. (2011). An Empirical Investigation of the Relation between Risk Tolerance and Socioeconomic Characteristics of Individual Investors. Advances in Management, 4(10), 60-65.

Sung, J., \& Hanna, S. (1996). Factors Related to Risk Tolerance. Financial Counseling and Planning, 7, 11-20.

Thaler, R. (1985). Mental Accounting and Consumer Choice. Marketing Science, 4(3), 199-214.

Tufan, E. (2008). Davranışsal Finans. Ankara: İmaj Yayıncılık.

Usul, H., Bekçi, I.., \& Eroğlu, A. H. (2002). Bireysel Yatııımcıların Hisse Senedi Edinimine Etki Eden Sosyo-Ekonomik Etkenler, Erciyes Üniversitesi Iktisadi ve Idari Bilimler Fakültesi Dergisi, 19, 135-150.

Wagner, J. (2011). An Empricial Analysis Linking a Person's Financial Risk Tolerance and Financial Literacy to Financial Behaviors. University of Nebraska Lincoln.

Wang, H., \& Hanna, S. (1997). Does Risk Tolerance Decrease With Age?. Financial Counseling and Planning, 8(2).

Watson, J., \& McNaughton, M. (2007). Gender Differences in Risk Aversion and Expected Retirement Benefits. Financial Analysts Journal, 63(4), 52-6 